\title{
Penyuluhan dan Pelatihan Kesehatan Gigi dan Mulut pada Masa Pandemi Covid-19
}

\author{
Nyka Dwi Febria1, Dian Yosi Arinawati² \\ 1Departemen Pendidikan Kedokteran, Kedokteran Gigi, Universitas Muhammadiyah Yogyakarta \\ 2Departemen Biologi Mulut, Kedokteran Gigi, Universitas Muhammadiayah Yogyakarta \\ Email: nica_dentist@yahoo.com \\ DOI: $10.18196 / p p m \cdot 34.274$
}

\begin{abstract}
Abstrak
Minimnya pengetahuan masyarakat tentang kesehatan gigi dan mulut serta rendahnya kesadaran masyarakat untuk memeriksakan kesehatan gigi menjadi dasar pengabdian masyarakat ini dilakukan. Pelaksanaan kegiatan ini dilakukan di masjid Al-Barokah desa Piring dengan peserta adalah Ibu-ibu pengajian. Tujuan pengabdian masyarakat ini adalah untuk dapat meningkatkan pengetahuan dan kesadaran kesehatan gigi dan mulut masayarakat. Masa pandemi Covid-19 ini merubah cara pengabdian masyarakat dengan menerapkan protokol yang sesuai. Protokol seperti cek suhu tubuh, pemakaian hand sanitizer dan masker diterapkan dalam kegiatan ini. Pelaksaan penyuluhan dilakukan pada 30 Ibu-ibu pengajian dan dipilih 10 orang dengan beberapa kriteria yang ditetapkan untuk dilakukan penyuluhan dan pelatihan. Kegiatan ini dilakukan melalui tahap pretest, penyuluhan, pelatihan dan posttest yang dilakukan pada tanggal 19 Juli 2020 di desa Piring Srihardono Pundong Bantul yang bertempat di Masjid Al-Barokah. Materi kegiatan pengabdian ini tentang kesehatan gigi dan mulut. Jumlah ibu pengajian berjumlah 75 orang, kemudian dikarenakan pandemi covid-19 maka diambil 30 orang untuk penyuluhan dan 10 orang untuk dilakukan pelatihan. Data diambil melalui kegiatan pretest dan posttest menunjukkan bahwa terdapat peningkatan pengetahuan masyarakat tentang Kesehatan gigi dan mulut. Peserta diharapkan dapat menerapkan pengetahuan kesehatan gigi dan mulut dalam perilaku kehidupan sehari-hari. Penyuluhan dan pelatihan kesehatan gigi dan mulut merupakan upaya yang tepat untuk dapat memberikan pengetahuan tentang kesehatan gigi dan mulut pada masayarakat.
\end{abstract}

Kata Kunci: penyuluhan kesehatan gigi dan mulut

\section{Pendahuluan}

Indonesia merupakan negara berkembang dengan keadaan ekonomi penduduk yang mayoritas menengah kebawah. Keadaan ini menjadi sebab diperlukan adanya dukungan dalam upaya untuk meningkatkan semua aspek kehidupan. Kesehatan merupakan salah satu aspek yang sangat perlu untuk diperhatikan. Hal ini mendorong berbagai pihak meningkatkan kesehatan masyarakat Indonesia. Salah satu aspek yang ditinjau adalah kesehatan gigi dan mulut. Kesehatan gigi dan mulut dipengaruhi oleh beberapa faktor, antara lain keturunan, lingkungan, perilaku, serta pelayanan kesehatan gigi dan mulut (Oktaria et al., 2016). Perilaku merupakan hal yang sangat penting diperhatikan dalam kesehatan gigi dan mulut. Perilaku yang dilakukan masyarakat tergantung dari pengetahuan yang dimiliki. Minimnya pengetahuan tentang kesehatan yang dimiliki masyarakat Indonesia menjadi penyebab terjadinya kerusakan pada gigi. Karies gigi adalah salah satu kerusakan gigi yang terjadi di Indonesia. Prevalensi karies gigi yang terjadi di Indonesia cukup tinggi, yaitu lebih dari 80\%. Hal ini berarti hampir semua mayasrakat Indonesia mengalami karies gigi (Fatimatuzzahro, Prasetya, \& Amilia, 2016). Karies gigi merupakan infeksi yang disebabkan oleh aktivitas bakteri dengan ditandai adanya kerusakan pada enamel, dentin dan sementum pada gigi. Karies dapat disebabkan oleh banyak faktor, antara lain: faktor tuan rumah, agen atau mikroorganisme, diet makanan dan ditambah faktor waktu. Karies gigi terjadi apabila semua faktor tersebut saling mendukung (Mitra, 2010). Karies gigi dapat menimbulkan berbagai gangguan dalam kehidupan seperti gangguan makan, berbicara, belajar, bekerja, dan bahkan gangguan tidur (Karlina, 2015). Karies gigi dapat dicegah dengan perilaku hidup sehat. Perilaku tersebut dapat terwujud jika pengetahuan tentang kesehatan gigi dan mulut sudah ada. Pengetahuan tersebut didapat dengan berbagai cara. Salah satunya dengan penyuluhan tentang kesehatan gigi dan mulut. Penyuluhan kesehatan gigi dan mulut memiliki tujuan dapat meningkatkan pengetahuan masyarakat untuk mencapai tingkat kesehatan gigi yang lebih baik. Penyuluhan kesehatan gigi dan mulut bukan hanya menjadi 
tangung jawab pemerintah, tetapi juga semua pihak yang berkompetance dalam bidang tersebut (Riyanti et al., 2010, Darwita et al., 2010, Simons et al., 2010).

Penyuluhan memilki sasaran untuk dapat mengubah perilaku individu atau masyarakat menjadi lebih baik. Hal ini ditekankan pada aspek kognitif sehingga diharapkan pengetahuan masyarakat tentang kesehtan gigi dan mulut meningkat serta dapat meningkatkan kesadaran masyarakat dan mengubah periku mayasarakat (Simons et al, 2010). Metode yang digunakan dalam penyuluhan yaitu sokratik. Sokratik yaitu penyuluhan dilakukan dengan dua arah. Masyarakat diberi kesempatan untuk mengemukakan pendapatnya dan penyuluh penyampaikan materi dengan demosntrasi. Demonstrasi dapat dilakukan dengan memberikan penjelasan secara lisan, gambargambar, dan ilustrasi. Metode ini dilakuan dengan mejelaskan suatu prosedur secara visual, sehingga mudah dipamhami dan masyarakat dapat mencoba pengetahuan tersebut (Hariyani et al., 2008). Penyuluhan yang dilakukan dalam masa pandemi covid-19 memiliki berbagai tantangan. Covid-19 adalah suatu penyakit yang disebabkan oleh coronavirus. Coronavirus adalah salah satu patogen utama yang menyerang sistem pernapasan pada manusia. Pada akhir Desember 2019, sekelompok pasien dirawat di rumah sakit dengan diagnosis awal pneumonia dengan etiologi yang tidak diketahui. Secara epidemiologi terkait dengan pasar hewan di

Wuhan, Provinsi Hubei, Cina (Bogoch et al., 2020, H. Lu et al., 2020). Gejala umum infeksi Covid-19 antara lain gejala gangguan pernapasan akut seperti demam, batuk, dan sesak napas. Masa inkubasi rata-rata 5-6 hari dengan masa inkubasi terlama 14 hari. Covid-19 dapat menyebabkan pneumonia, sindrom pernapasan akut, gagal ginjal, dan bahkan kematian (Holshue et al., 2020; Perlman, 2020). Indonesia telah melaporkan 2 kasus terkonfirmasi Covid19 pada tanggal 2 Maret 2020. Terhitung sejak 29 Maret 2020 sudah meningkat menjadi 1.285 kasus di 30 provinsi (Kementerian Kesehatan Republik Indonesia, 2020). Peningkatan jumlah kasus berlangsung cukup cepat dan telah terjadi penyebaran antar negara. Menyikapi hal itu, WHO menetapkan Covid-19 sebagai pandemi (Cucinotta dan Vanelli, 2020).

Berdasarkan hal tersebut diatas penyuluhan dan pelatihan tentang kesehatan gigi dan mulut diperlukan adanya beberapa protokol kesehatan khusus yang harus ditaati. Sehingga diharapkan tidak berdampak buruk dan menimbulkan peningkatan jumlah penularan covid-19. Tujuan dari kegiatan pengabdian masyarakat ini adalah meningkatkan pengetahuan Ibu-ibu mengenai pentingnya menjaga kesehatan gigi dan mulut. Tujuan kegiatan pengabdian masyarakat berupa penyuluhan dan pelatihan kesehatan gigi dan mulut ini adalah untuk menumbuhkan kesadaran hidup sehat, membangun kebiasaan untuk dapat menerapkan cara menggosok gigi benar dalam kehidupan sehari-hari, serta melatih untuk selalu menjaga kesehatan gigi dan mulut.

\section{Metode Pelaksanaan}

Penyuluhan ini berupa rangkaian kegiatan yang dilakukan untuk penyuluhan dan pelatihan tentang kesehatan gigi dan mulut. Kegiatan ini dilakukan di Masjid Al-Barokah Desa Piring Srihardono Pundong Bantul dengan peserta penyuluhan sebanyak 30 orang. Antusias peserta dalam kegiatan ini sangat tinggi dibuktikan dengan jumlah Ibu-Ibu yang menginginkan hadir 75 orang peserta. Pelaksaan ini dilakukan dengan persiapan yang matang dikarenakan dalam keadaan covid-19. Hasil dari musyawarah yang dilakukan bersama penggurus masjid, peserta yang diperbolehkan hadir hanya 30 orang. Sedangkan untuk peserta penyuluhan dan pelatihan sebanyak 10 orang dengan kriteria berupa peserta pelatihan wajib bisa membaca dan menulis, peserta bisa mengikuti sampai selesai, dan peserta menyetujui ikut dalam kegiatan. Kegiatan ini dilakukan pada tanggal 19 Juli 2020. Waktu kegiatan dilakukan selama 2 jam dikarenakan masa covid-19 sehingga semua waktu diatur untuk dapat memaksimalkan kegiatan. Metode kegiatan pengabdian kepada masyarakat dilakukan oleh Tim Prodi Kedokteran Gigi 
Fakultas Kedokteran dan Ilmu Kesehatan Universitas Muhammadiyah Yogyakarta. Pelaksanaan kegiatan meliputi:

\begin{tabular}{lll}
\hline Tahap & Kegiatan & \\
\hline Persiapan & $\begin{array}{l}\text { Penyelenggara menyediakan dan mengatur lokasi } \\
\text { dengan pemberian jarak antara peserta minimal 1 } \\
\text { meter. Dengan memberikan tanda ditempat yang } \\
\text { akan diduduki. }\end{array}$ & \\
& $\begin{array}{l}\text { Peserta wajib memakai masker } \\
\text { Peserta wajib cek suhu tubuh } \\
\text { Memakai handsanitiser } \\
\text { 10 peserta pelatihan dan penyuluhan } \\
\text { 30 peserta penyuluhan (Pemberian edukasi dengan } \\
\text { audiovisual, LCD, ppt yang menarik) }\end{array}$ & $\begin{array}{l}\text { Penyuluhan kesehatan gigi dan } \\
\text { mulut }\end{array}$ \\
Pelaksanaan & $\begin{array}{l}\text { Materi : Cara menjaga kesehatan gigi dan mulut, } \\
\text { karang gigi, dan perawatan gigi } \\
\text { 10 peserta pelatihan }\end{array}$ & \\
& & $\begin{array}{l}\text { Praktek penggunaan alat cek } \\
\text { suhu tubuh (thermometer), } \\
\text { tanda-tanda karies gigi. }\end{array}$ \\
& $\begin{array}{l}\text { 10 peserta pelatihan dan penyuluhan } \\
\text { Diakhiri dengan berfoto bersama }\end{array}$ & \\
\hline
\end{tabular}

\section{Hasil dan Pembahasan}

Pelaksanaan kegiatan dilakukan dengan lancar sesuai dengan jadwal yang sudah ditentukan pada tahap persiapan. Kegiatan diawali dengan pengecekan pemakaian masker, pengecekan suhu tubuh, pengecekkan kehadiran, dibuka dengan pembacaan ayat suci Al-Quran dan sambutan dari takmir masjid. Pemateri pertama menyampaikan tentang pentingnya menjaga kesehatan gigi dan mulut. Pemateri kedua penyampaikan tentang penyebab karang gigi dan perawatannya. Penambahan materi dan teori penggunaan thermoter juga dilakukan dalam pengabdian ini. Hal tersebut disebabkan karena pada saat wabah masyarakat ingin mengetahui bagaimana cara penggunaan thermometer digital. Pada saat edukasi semua peserta memperhatikan dengan sungguh-sungguh. Beberapa pertanyaan langsung disampaikan kepada pembicara ketika selesai penyampaikan materi. Hambatan peserta saat melakukan edukasi adalah sulit untuk membiasakan menyikat gigi secara teratur minimal 2 kali sehari dengan cara yang benar dan waktu yang tepat, periksa ke dokter gigi minimal 6 bulan sekali ke dokter gigi. Masyarakat hanya datang ke dokter gigi jika merasa ada keluhan berupa sakit gigi yang sebelumnya telah dibelikan obat di apotik dan tidak sembuh.

Keberhasilan kegiatan ini dapat dilihat dari antusiasnya peserta kegiatan dan banyaknya pertanyaan yang diajukan. Setelah diberikan penyuluhan tentang kesehatan gigi dan mulut diharapkan ibu-ibu dapat memahami dan mengaplikasikan dalam kehidupan sehari-hari.

Gambar 1. Penyuluhan Kesehatan Gigi dan Mulut




Gambar 3. Hasil Pretest dan Posttest



Kesehatan gigi dan mulut merupakan salah satu hal yang perlu diperhatikan. Hal tersebut dikarenakan dengan gigi yang sehat maka semua aktifitas dapat berjalan dengan baik. Kebiasaan mengkonsumsi makanan dan minuman yang banyak mengandung gula merupakan komponen penting dalam terjadinya karies gigi. Beberapa faktor yang menyebabkan karies gigi antara lain pengalaman karies, kebersihan mulut, plak gigi, susunan gigi, kebiasaan makan dan minum yang mengandung gula, cara menggosok gigi, usia, jenis kelamin, ras dan budaya, merokok, status ekonomi, dan tinggkat Pendidikan (Tmis, 2005). Karies gigi diperlukan perawatan sejak dini, sehingga tidak menyebabkan kerusakan yang lebih buruk lagi seperti harus dilakukan pencabutan gigi. Apabila seseorng kehilangan giginya makan akan mengalami masalah dalam pengunyahan, malu, dan dapat membatasi interaksi social (Yaday dan Prakash., 2016). Karang gigi atau kalkulus merupakan kerak yang menempel pada gigi, berwarna kuning sapai kehitaman, terasa kasar, dan dapat menyebabkan beberapa masalah pada gigi. Karang gigi juga merupakan salah satu yang mempengaruhi kesehatan gigi dan mulut. Karang gigi yang tidak dibersihkan akan menyebabkan kerusakan jaringan pendukung gigi. Hal tersebut akan berakibat juga terjadi kegoyahan pada gigi dan akibat yang lebih parah dapat menimbulkan kehilangan gigi. 
Kurangnya pengetahuan seseorang tentang kesehatan gigi dan mulut akan berpengaruh pada perilaku kesehatan yang dilakukan dalam kehidupan sehari-hari. Kesehatan gigi dan mulut sangat erat kaitannya dengan perilaku yang dilakukan seseorang untuk menjaga Kesehatan tersebut (Budiharto, 2010). Pengabdian masyarakat ini dapat meningkatkan pengetahuan masyarakat tentang kesehatan gigi dan diharapkan dapat dilakukan dalam kehidupan sehari-hari. Pengetahuan masyarakat dalam penyuluhan ini meningkat dengan meningkatnya hasil pretest dan potstest yang dilakukan. Peningkatan pengetahuan tersebut sejalan dengan pelaksaan penyuluhan. Pada saat penyuluhan masyarakat sangat antusias mengajukan bermacam-macam pertanyaan yang berkaitan dengan kesehatan gigi dan mulutnya. Banyaknya pertanyaan yang disampaikan oleh masyarakat menjadi dasar bahwa semakin meningkatnya pengetahuan. Masyarakat sangat tertarik ketika dijelaskan beberapa hal terkait karang gigi. Karang gigi yang sama sekali belum dipahami jika pembersihan karag gigi diperlukan dalam perawatan kesehatan gigi dan mulut. Penyuluh menampilkan beberapa media baik berupa gambar atau video dimana karang gigi ternyata banyak dijumpai pada rongga mulut masyarakat. Penjelasan mengenai pembentukan karang gigi dan akibat yang dapat ditimbulkandari adanya karang gigi tidak disadari oleh masyarakat. Pengabdian ini memberikan edukasi kepada ibu-ibu bagaimana cara merawat gigi dari karang gigi.

Proses karies dalam penyuluhan ini, sebagian ibu-ibu sudah mengetahui. Karena ada beberapa dari mereka yang datang ke dokter gigi ketika giginya terasa sakit. Tetapi ada yang hanya membelikan obat diapotik. Karies gigi merupakan pengetahuan yang sudah banyak diketahui karena karies yang sudah dalam akan menyebabkan gangguan berupa rasa sakit yang sangat mengganggu. Penyuluhan ini memberikan edukasi bagi peserta bagaimana jika sudah terjadi karies sejak masih tahap awal harus segara diperiksakan ke dokter gigi sebelum terjadi rasa sakit. Peserta juga diberi pengetahuan bagaimana cara melihat tanda-tanda karies berupa warna kehitaman dan tedapat lubang pada gigi.

Penyuluhan dan pelatihan kesehatan gigi dan mulut pada masa covid-19 sangat terbatas untuk pelaksaannya. Penyuluh harus mematuhi beberapa aturan sehingga penyuluhan dan pelatihan tersebut dapat dilakukan. Penyebaran covid-19 yang dapat terjadi melalui droplet akan menyebabkan penularan pada saat perawatan gigi dan mulut. Covid-19 memaksa penyuluh untuk merubah beberapa bagian dari pelaksanaan penyuluhan dan pelatihan yang seharusnya dilakukan. Pemeriksaan gigi dan mulut pada masa covid-19 juga dijelaskan oleh penyuluh. Peserta penyuluhan merasa jelas dan mengetahui waktu yang tepat untuk memeriksakan kesehatan gigi dan mulutnya pada saat covid-19. Kegiatan tambahan dalam pengabdian masyarakat ini yaitu pengetahuan dan pelatihan terkait penggunaan thermometer. Thermometer yang digunakan pada saat ini adalah thermometer khusus dengan jarak dan waktu yang singkat sudah dapat untuk mengetahui suhu tubuh seseorang. Pelatihan pemakaian thermometer diperlukan sehingga protokol kesehatan akan diterapkan setelah penyuluhan dan pelatihan ini. Peserta akan menerapkan pemeriksaan suhu tubuh yang sudah dilatihkan dalam pengabdian sebelum melakukan kegiatan di masjid.

\section{Simpulan}

Kesehatan gigi dan mulut merupakan salah satu bagian kesehatan yang harus dijaga. Pengetahuan yang cukup menjadi dasar untuk dapat diwujudkan dalam perilaku kehidupan sehari-hari. Oleh karena itu, edukasi dan demonstrasi kebersihan gigi dan mulut dilakukan dalam pengabdian ini. Hasil pengabdian masyarakat ini masih perlu dikembangkan dengan menjalin kerjasama dengan pengurus setempat. Masa pandemic covid-19 yang semoga segera berlaku sehingga kegiatan ini dapat dilakukan untuk pembersihan gigi peserta berupa skaling ultrasonic dengan memeriksa tingkat kebersihan gigi. 


\section{Ucapan Terima Kasih}

Kami mengucapkan terima kasih kepada Universitas Muhammadiyah Yogyakarta sebagai pemberi dana pengabdian, bapak dan Ibu pengurus Masjid Al-Barokah, Ibu-ibu pengajian sebgai peserta, tim yang ikut tergabung dalam pelaksanaan dari perencanaan hingga berlangsungnya acara yang sudah memberikan waktu dan kesempatan kepada kami untuk melakukan salah satu Tridarma di Perguruan

\section{Daftar Pustaka}

Bogoch, A. Watts, A. Thomas-Bachli, C. Huber, M.U.G. Kraemer, K. Khan, Pneumonia of unknown etiology in wuhan, China: potential for international spread via commercial air travel, J. Trav. Med. (2020), https://doi.org/10.1093/jtm/ taaa008.

Budiharto , 2010. Pengantar Ilmu Perilaku Kesehatan dan Pendidikan Kesehatan Gigi. Jakarta: EGC.

Cucinotta D., Vanelli M. WHO declares COVID-19 a pandemic. Acta bio-medica: Atenei Parmensis. 2020;91;157 [PMC free article] [PubMed] [Google Scholar]

Darwita RR, Rahardjo A, Amalia R. Penerimaan guru SDN 03 Senen terhadap program sikat gigi bersama di dalam kelas pada murid kelas 1 dan 2. Cakradonya Dent J 2010; 2(2): 159-250.

Fatimatuzzahro, N., Prasetya, R. C., \& Amilia, W. (2016). Gambaran Perilaku Kesehatan Gigi Anak Sekolah Dasar di Desa Bangalsari Kabupaten Bantaeng. Jurnal IKESMA, 12(2), 85.

Hariyani N, Setyo L, Soedjoko. Mengatasi kegagalan penyuluhan kesehatan gigi pada anak dengan pendekatan psikologi. Dentika Dent J 2008; 13: 80-4.

H. Lu, C.W. Stratton, Y.W. Tang, Outbreak of pneumonia of unknown etiology in wuhan China: the mystery and the miracle, J. Med. Virol. 92 (4) (2020) 401-402, https://doi.org/10.1002/jmv.25678.

Holshue M.L., DeBolt C., Lindquist S., Lofy K.H., Wiesman J., Bruce H. First case of 2019 novel coronavirus in the United States. N. Engl. J. Med. 2020 [Google Scholar]

Kementerian Kesehatan Republik Indonesia . 2020. Pedoman Pencegahan dan Pengendalian Corona Virus Diaseases (COVID-19) [Google Scholar]

Mitra M. Hubungan Status Karies Dan Gingivitis Dengan Oral Hygiene Pada Anak Usia 6-12 Tahun Di Desa Ujung Rambung Kecamatan Pantai Cermin Kabupaten Serdang Bedagai. 2010:13.

Oktarina, Tumaji, \& Roosihermiatie, B. (2016). Korelasi Faktor Ibu Dengan Status Kesehatan Gigi Dan Mulut Taman Kanak-Kanak di Kelurahan Kemayoran Kecamatan Krembangan, Kota Surabaya. Pusat Penelitian Dan Pengembangan Humaniora Dan Manajemen Kesehatan, 19(17), 226-235. 
Perlman S. Another decade, another coronavirus. Mass Medical Soc. 2020 [PMC free article][PubMed] [Google Scholar]

Riyanti E, Chemiawan E, Rizalda RA. Hubungan pendidikan penyikatan gigi dengan tingkat kebersihan gigi dan mulut siswa-siswi Sekolah Dasar Islam Terpadu (SDIT) Imam Bukhari. Diunduh dari: http://studentresearch. 